\title{
An Overview of Florida Water Policy Framework and Institutions ${ }^{1}$
}

\author{
Jarrett Davis, Tatiana Borisova, and Michael T. Olexa²
}

\section{Preface}

This publication is a part of the Handbook of Florida Water Regulation. The handbook is designed to provide an accurate, current, and authoritative summary of the principal federal and state laws that directly or indirectly relate to agriculture in Florida. This handbook provides a basic overview of the many rights and responsibilities that farmers, farmland owners, and other Florida residents and businesses have under both federal and state laws, as well as the appropriate contact information to obtain more detailed information. However, the reader should be aware that because the laws, administrative rulings, and court decisions on which this handbook is based are subject to constant revision, portions of this publication could become outdated at any time. Several details of cited laws are also left out due to space limitations.

This handbook is distributed with the understanding that the authors are not engaged in rendering legal or other professional advice, and the information contained herein should not be regarded as a substitute for professional advice. This handbook is not all inclusive in providing information to achieve compliance with the federal and state laws and regulations governing water protection. For these reasons, the use of these materials by any person constitutes an agreement to hold harmless the authors, the Florida Cooperative Extension Service, the Institute of Food and Agricultural Sciences, and the University of Florida for any liability claims, damages, or expenses that may be incurred by any person as a result of reference to or reliance on the information contained in this handbook.

\section{What This Document Is About}

This publication is intended to provide a background on the history of Florida laws developed to address various regional and statewide water challenges. It also provides an overview of laws and regulations governing water resource use.

This publication also provides a summary of laws and regulations discussed in the other chapters of this Handbook, and is intended to help the reader find the relevant Handbook section. The reader can find the relevant section of this Handbook by examining the topics listed in the table of contents below. The reader can also use the table of contents for the handbook as a whole available at http:// edis.ifas.ufl.edu/fe579.

\section{Contents}

Florida's Water Resources: Defining the Way of Life and Driving the Economy

Why do we need water policies and regulations?

1. This document is FE1043, one of a series of the Food and Resource Economics Department, UF/IFAS Extension. Original publication date October 2018. Visit the EDIS website at https://edis.ifas.ufl.edu for the currently supported version of this publication.

2. Jarrett Davis, student, Levin College of Law; Tatiana Borisova, associate professor, Food and Resource Economics Department; and Michael T. Olexa, professor, Food and Resource Economics Department, and director, UF/IFAS Center for Agricultural and Natural Resource Law; UF/IFAS Extension, Gainesville, FL 32611

The Institute of Food and Agricultural Sciences (IFAS) is an Equal Opportunity Institution authorized to provide research, educational information and other services only to individuals and institutions that function with non-discrimination with respect to race, creed, color, religion, age, disability, sex, sexual orientation, marital status, national origin, political opinions or affiliations. For more information on obtaining other UF/IFAS Extension publications, contact your county's UF/IFAS Extension office. 
History of Water Regulation in Florida

Keystone of the Florida Water Policy and Law: The Florida Water Resources Act of 1972

Government Agencies Involved in Water Resource Planning and Management

Water Use and Availability into the Future: Statewide and Regional Water Supply Planning

Water Use and Availability: Water Resource Management through Permitting

Managing and Protecting Water Quality in Streams, Lakes, and Other Surface Water Bodies

Protecting the Quality of Groundwater

Protecting Water Quality: The Florida Department of Environmental Protection as The Lead State Agency

Addressing Water Pollution Issues in Florida

Protecting the Coast and Coastal Waters

Protecting Wetlands

Protecting Endangered Species

Other Programs and Laws

List of Government Agencies Involved in Water Resource Management

Conclusions

References

\section{Florida's Water Resources: Defining a Way of Life and Driving the Economy}

Water resources define Florida's unique character. Among the most recognizable symbols of Florida, one can find its top-ranked beaches, lush tropical vegetation, wetlands wildlife, and parks and waterparks, all of which depend upon clean and abundant water. Florida is also home to a strong agricultural industry, with many crops, such as citrus, requiring irrigation. Water is also required to meet the needs of Florida's growing population, to support its fragile ecosystems, and to grow agricultural products and provide other goods and services.
Overall, with the diverse and increasing water needs, wise management of water resources is important, and laws are set in place to regulate water use and protect the environment, with various government agencies having diverse roles and responsibilities.

\section{Why do we need water policies and regulations?}

The supply and use of many goods, such as corn, cars, or electronics, are regulated by markets, with prices helping to allocate these goods among people. Water has unique characteristics, differentiating it from other products, and complicating market functioning and water allocation. Specifically, water is a basic need of people, making private property rights and market-based allocation difficult and often morally unjust. Furthermore, water constantly moves from place to place, making water users dependent on each other in complex ways. For example, a portion of water withdrawn from a canal for irrigation runs back to the canal as a return flow. However, the proportion returned to the canal depends on the crops' water needs, the weather, the type of irrigation system used, and the soils and geology of the area, all of which are hard to assess and account for. Furthermore, in some situations, water resource use is impossible to control or preclude (e.g., water-based recreation on a river). Given these unique characteristics, private property rights for water are difficult to define, and this precludes markets from functioning and efficiently allocating water among diverse users. Therefore, alternative mechanisms, such as formal or informal agreements among the members of a society, are needed to regulate the use of water resources.

In fact, the water laws and regulations discussed in this and other handbook chapters are the formal rules created by societies to regulate water resource use and protection. Developing these rules took some time. Water use in Florida started out mostly unregulated, and landowners could legally use water however they desired. However, with increases in the number of people in the state, greater water needs, and growing knowledge about impacts of use on the other water users and the water resource itself, Florida began regulating water use to protect water quality, extend water availability, and allow for non- human uses (such as providing habitat for aquatic plants and animals). 


\section{History of Water Regulation in Florida}

Before 1972, Florida's water law was based on common law doctrines that had evolved in the eastern United States beginning in colonial times. Florida followed the common law eastern riparian doctrine, which essentially provided landowners with absolute ownership of water on their property and the right to use it on their property so long as it did not unreasonably interfere with another landowner's right. Underground waters that flowed in definite channels (i.e., waters in the aquifer) were covered under the riparian doctrine, however, percolating waters, which are waters that flow without any permanent or definite channel (i.e., rain waters seeping through the ground) were not covered under the riparian doctrine. Additionally, the doctrine did not address water quality because in the 1970s, scientific knowledge about the impacts of certain actions on the quality of surface and groundwater was limited.

Water-use conflicts that developed over time led the courts and the legislature to refine the water laws and regulations. Specifically, in 1958, in the landmark case, Koch v. Wick, the Florida Supreme Court narrowed the scope of waterfront property-owners' right to use water on their property. The Court adopted the reasonable use rule, which, like the eastern riparian doctrine, gave all property owners an equal right to use the water located on their property, as long as it did not cause harm to other property owners. However, the reasonable use rule was subject to the condition that water use should be reasonably related to the natural use of the landowner's property (in other words, purchasing land to withdraw and sell water was not a reasonable use of land). This reasonable use rule applied to surface and groundwater, including percolating waters.

Before the 1950s, Florida managed its water resources through single purpose districts, which were tasked with addressing specific problems within specifically defined boundaries (i.e., mosquito-control districts, flood-control districts, and irrigation districts). In the late 1960s, faced with a rapidly growing state population, policymakers and water managers began to argue for a more cohesive solution to water quality and quantity problems, and for more integration in state regulatory and government agencies. In 1972, the Florida legislature responded by enacting the Florida Water Resources Act of 1972.

\section{Keystone of the Florida Water Policy and Law: The Florida Water Resources Act of 1972}

The Florida Water Resources Act of 1972 (Chapter 373, Florida Statutes), henceforth, "the Act," was largely based on the Model Water Code, which was a scholarly review of Florida's surface water, groundwater, diffused surface water, and water pollution. The Model Water Code was published by Dean Frank E. Maloney and his colleagues at the University of Florida. The code integrated concepts from the common law water rights doctrines (which includes the reasonable use rule; See Maloney, Florida's New Water Resources Law, 10 U. FLA. L. REV. 119 (1957).

The fundamental structure of the Act has stood the test of time. The Florida legislature has added provisions to address new issues, but the purpose and structure remain the same as in 1972.

\section{Government Agencies Involved in Water Resource Planning and Management}

Before the passage of the Act, only two Water Management Districts (WMDs) existed. These were the Southwest Florida WMD and the Central and Southern Florida Flood Control District (the predecessor to the South Florida WMD). The Act established five Water Management Districts and provided the regulatory agencies the responsibility of addressing issues such as water supply, drainage/ flood protection, water quality, and protection of natural resources (See Fla. Stat. \$373.026). The Act divided Florida into five WMDs, with the districts' boundaries determined by the five major water basins in the state: the Northwest Florida WMD, St. Johns River WMD, the Suwannee River WMD, the South Florida WMD, and the Southwest Florida WMD. By establishing five WMDs, the Act provided a statewide comprehensive approach to solving water issues. Under the Act, all five WMDs (Figure 1) were assigned the same mandates and responsibilities. For more information regarding WMDs, see the "Florida Water Management Districts" section in this handbook at http://edis.ifas.ufl. edu/fe594.

While WMDs address regional issues, according to the Act, statewide authority for water resource management is vested in the Florida Department of Environmental Protection (FDEP 2013a). The FDEP has general supervisory authority over the WMDs and delegates water resources 
programs to the WMDs wherever possible. The legislative intent was to provide for the continuity of the statewide water management policy, with regional implementation taking into account the variability of water resources in the state. For additional information about FDEP, see the "Florida Department of Environmental Protection" section in this handbook at http://edis.ifas.ufl.edu/fe593.

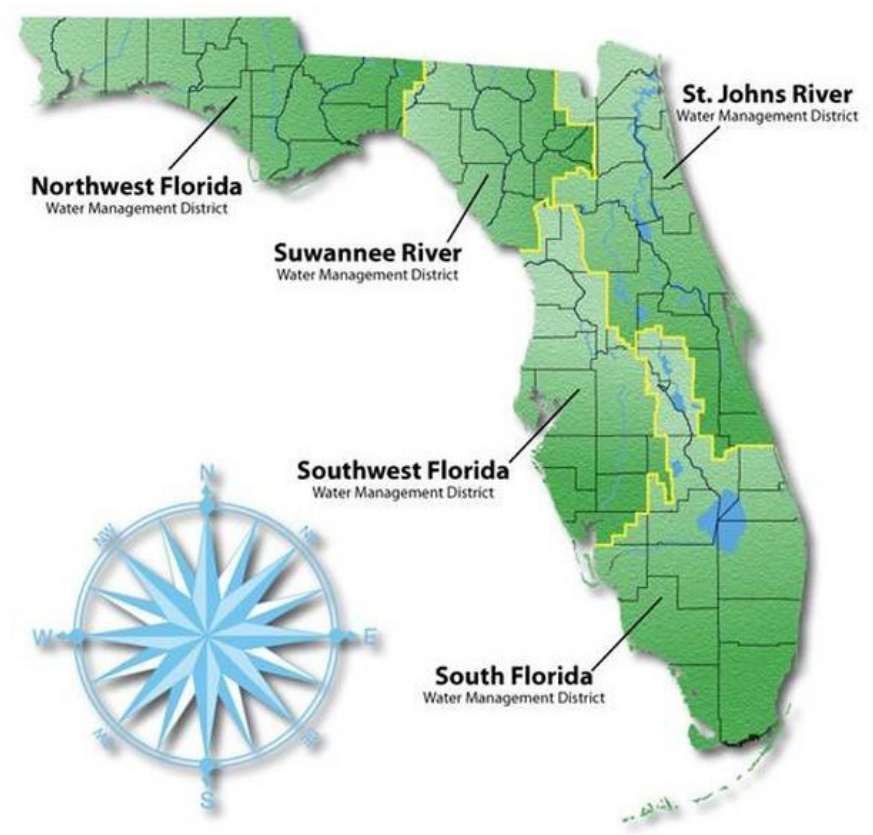

Figure 1. Florida's Five Water Management Districts Credits: St. Johns River Water Management District (2017), about the district. http://www.sjrwmd.com/maps.html

The Act grants each district the authority to subdivide itself into basin boards, which are to be composed of three to five members. The members are responsible for planning water resource development projects and providing guidance to local governments and private local owners on water control facilities.

\section{Water Use and Availability into the Future: Statewide and Regional Water Supply Planning}

The Florida Water Resources Act of 1972 provides the five Florida WMDs with the planning responsibilities to address current issues and prevent future problems from occurring. These responsibilities include developing short- and longterm water-supply plans and providing feedback on local government comprehensive water plans. The five WMDs were directed to develop regional water supply plans, which are intended to estimate the needs for water for various uses (such as public water supply and agriculture), and to balance these with the protection of environmental systems. Specifically, a five-year water resource development work program must describe water supply components to guarantee the water supply needs of existing and future reasonable-beneficial uses for a 1-in-10-year drought event (373.536(6)(a)4, Florida Statutes). Annually, FDEP submits to the governor and the state legislature a report about the status of regional water supply planning (373.709(6), Florida Statutes; Regional Water Supply Planning).

\section{Water Use and Availability: Water Resource Management through Permitting}

Another highlight of the Florida Water Resources Act was the emphasis upon environmental protection through the permit programs that regulate water withdrawals and alterations of the surface water flows.

Instead of the absolute landowners' ownership for water adjacent and under their property (as was practiced under the historical riparian rights doctrine), Florida water resources are owned by the state, and their use is regulated by permits issued by WMDs.

Consumptive water use permits (or water use permits) (Authorized by Part II of Chapter 373) allow surface and groundwater withdrawals for beneficial use such as public water supply, agricultural and landscape irrigation, industrial use, and power generation (Florida's Water Management Districts Permitting Portal 2013). Individual permits are required for water withdrawals above certain limits (set for annual average daily withdrawal volumes or well diameters). Applicants for the individual permits must establish that the intended use is a reasonable-beneficial use, that it is consistent with the public interest, and that it does not interfere with any existing permitted water uses, as well as Minimum Flows and Levels set for lakes, wetlands, and aquifers. For more information about the regulations related to the consumptive use permits, see the "Consumptive Use" Chapter of this handbook at http://edis.ifas.ufl. $\mathrm{edu} / \mathrm{fe} 604$.

Permits may also be required for well installation to ensure that wells meet standards for safety and durability and to safeguard both the quality of water extracted from the wells and the quality of the source (aquifer) water. The permits are issued by WMDs (see the "Water Wells" chapter in this handbook at http://edis.ifas.ufl.edu/fe603).

Finally, alterations to the hydrologic regime (such as management and storage of surface water) are regulated by Environmental Resource Permits, also issued by the 
WMDs. Environmental Resource Permits are required for activities that change surface water flow (e.g., a construction project that will increase stormwater flow, see FDEP 2013b). There is a variety of Environmental Resources Permits. You can learn about them in other chapters of this handbook.

\section{Managing and Protecting Water Quality in Streams, Lakes, and Other Surface Water Bodies}

The federal Clean Water Act (CWA) establishes the basic regulatory structure for the discharge of pollutants and sets quality standards for surface water (such as lakes, rivers, and streams) in all states in the United States. The goal of the CWA is to maintain and restore the chemical, physical, and biological integrity of navigable waters. The CWA provides states with the responsibility of reviewing, establishing, and revising water quality standards. For more information, see the "Clean Water Act" chapter in this handbook at http://edis.ifas.ufl.edu/fe582.

The Total Maximum Daily Load (TMDL) program is among the major programs implemented by FDEP to address water quality issues in the state (FDEP2013c). The CWA requires states to submit a list of surface waters that do not meet water quality standards (referred to as "impaired"), and to establish TMDL limits for these waters. A TMDL is the total amount of pollution that a water body can receive over a certain period of time (usually, a year) and still meet water quality standards.

Section 303(d) of the CWA requires states to compile a list of impaired waters, which they must submit to the EPA every two years for approval. States assign a priority ranking for establishing TMDLs in the waterbody. The ranking is prioritized based on the severity of the pollution and the designated use of the waterbody (i.e., potable water supplies or human recreation).

The Florida Legislature enacted the Florida Watershed Restoration Act (FWRA) in 1999 to protect Florida's waters and to apply and extend federal requirements related to the TMDL program and the CWA to the state of Florida. Florida's water quality standards are published in the Florida administrative code at 62-302 and 62-302.530. The topics covered in the administrative code include: classifications, criteria, an anti-degradation policy, and protection of outstanding Florida waters. In Florida, the TMDL process includes the identification, verification, and listing of impaired waters; development of the TMDL plan with the initial allocation of allowable loads among polluting sources; and the TMDL implementation plan, referred to as the basin management action plan (BMAP), with a list of measures and projects to achieve TMDL and an evaluation of strategy to judge the progress. These steps are followed by BMAP implementation, progress monitoring and evaluation, and BMAP modifications if water quality targets are not achieved. For more information, see the "Florida Watershed Restoration Act" chapter in this handbook at http://edis.ifas.ufl.edu/fe608.

In addition to the TMDL program, to prevent harm to Florida's waters, both the FDEP and Florida WMDs are vested with the authority to require permits for the management and storage of surface water permits and impose conditions on those permits. This authority is delegated almost entirely to FWMDs, which should be consulted before any alteration of surface water is undertaken. At the most basic level, the planned activity cannot be against the public interest. For more information on the management and storage of surface waters, see the "Management and Storage of Surface Waters" chapter in this handbook at http://edis.ifas.ufl.edu/fe605.

Farmers interested in limiting their exposure to unwanted penalties and liabilities related to the potential impact on water resources should use BMPs. FDEP, FDACS, WMDs, and USDA have provided both cost-share and technical assistance to farmers to help implement BMPs to reduce point-source and nonpoint-source pollution from agriculture operations. For more information on environmentally safe practices, see the handbook chapter at http://edis.ifas. ufl.edu/fe600.

\section{Protecting the Quality of Groundwater}

Almost all water used by Floridians for household needs is withdrawn from the Floridan aquifer (groundwater). The federal Safe Drinking Water Act (SDWA) passed in 1974 aims to eliminate the pollution in drinking water by protecting water quality from the source to the tap. (See the SDWA chapter of this handbook at http://edis.ifas.ufl.edu/ fe587.) In Florida, the SDWA is implemented under the primacy of the state, rather than federal agencies, a designation of the Florida Safe Drinking Water Act of 1977.

Discharge of waste into state waters (including groundwater) is prohibited unless permitted by a state agency. A discharge activity is not permitted if the contaminants reduce ground or surface water quality below the standards required by the FDEP. For more information on 
groundwater discharge regulations at the state level, see discussion of the state and federal groundwater discharge regulations in the corresponding chapters of this handbook at http://edis.ifas.ufl.edu/fe601 (state) and http://edis.ifas. ufl.edu/fe602 (federal).

Two more state regulatory acts are intended to protect groundwater quality: the Florida Water Quality Assurance Act of 1983 and the Florida Underground Petroleum Environmental Response Act of 1986. The Florida Water Quality Assurance Act addressed the need to compile data related to water resources; prevent contamination of potable water supplies; plug abandoned artesian wells; regulate the siting of septic tanks; clean up existing contamination sites; prevent pollution from leaking from underground fuel storage tanks; and require the proper treatment, storage, and/or disposal of all hazardous wastes. For more information about onsite sewage treatment and disposal covered by the Florida Water Quality Assurance Act, see "Onsite Sewage Treatment and Disposal" chapter at http://edis.ifas. ufl.edu/fe614. In turn, the Florida Underground Petroleum Environmental Response Act further addressed the need to prevent pollution from leaking from underground petroleum storage tanks and to fund the cleanup of existing pollution sites. For more information, see the "Pollutant Storage Tank Systems" chapter in this handbook at http:// edis.ifas.ufl.edu/fe613.

\section{Protecting Water Quality: The Florida Department of Environmental Protection as the Lead State Agency Addressing Water Pollution Issues}

Along with several other laws, the Air and Water Pollution Control Act as amended (Chapter 403, Florida Statutes) provides the statutory basis for the regulation of most of the aspects of water quality in Florida. This law provides FDEP with broad powers and duties to accomplish the statutory goal of protecting and improving water quality throughout the state. These include the power to classify surface and groundwater bodies according to their most beneficial uses (e.g., potable water supply or recreation); establish ambient water-quality criteria for various parameters of water quality; develop standards of quality for wastewater discharges; implement a permit system for the operation, construction, or expansion of any installation that may be a source of water pollution; and require posting bond to operate any such installation. (For more information on the Air and
Water Pollution Control Act, see the relevant chapter in this handbook at http://edis.ifas.ufl.edu/fe607).

\section{Protecting the Coast and Coastal Waters}

The Florida Pollutant Discharge Prevention and Control Act is intended to maintain and protect the coast and coastal waters, beaches, and public lands that adjoin it in as close to a pristine condition as possible. It empowers and provides a trust fund, the Florida Coastal Protection Trust Fund (FCPTF), for FDEP and the Florida Fish and Wildlife Conservation Commission (FFWCC) to regulate, investigate, rehabilitate, and clean up sites contaminated by spills and discharges of substances and pollutants occurring as a result of procedures involved in the storage, transportation, and transfer of these substances and pollutants between ships, onshore facilities, offshore facilities, and terminal facilities within the jurisdiction and waters of Florida, and from saltwater traps impregnated with pollutants. See more in the relevant chapter of this handbook at http://edis.ifas. ufl.edu/fe585.

\section{Protecting Wetlands}

The regulation of wetlands is carried out at the federal level by the Army Corps of Engineers and at the state level by FDEP. See more at http://edis.ifas.ufl.edu/fe606 ("Activities in Wetlands" chapter).

South Florida's unique wetland, the Everglades, is extremely important for both Florida, the nation, and the world. It was designated as a Wetland Area of Global Importance by UNESCO. To restore and protect the system, several pieces of legislation were passed on the state level. The Florida Everglades Forever Act (FEFA) includes provisions for water supply improvement and restoration, the Everglades research and monitoring program, evaluation of water quality standards, monitoring and controlling exotic species, and other programs important for the Everglades (see http://edis.ifas.ufl.edu/fe609). In turn, the Northern Everglades and Estuaries Protection Program focuses on improving and protecting the water quality and quantity in the Lake Okeechobee, Caloosahatchee River, and St. Lucie River watersheds, all hydrologically connected with the Everglades (NEEPP, 373.4595, Florida Statutes). See more at http://edis.ifas.ufl.edu/fe610. 


\section{Protecting Endangered Species}

The federal Endangered Species Act protects species of fish, wildlife, and plants that are threatened with extinction as well as the ecosystems critical to the survival of those species. To find out more, see the "Endangered Species Act" chapter of this handbook at http://edis.ifas.ufl.edu/fe592.

\section{Other Programs and Laws}

Water quality and availability can be affected by a variety of human activities, and, hence, various government programs have been developed to protect and restore the environment, including water resources.

For example, the manufacturing and handling of toxic chemicals and the management of hazardous substances and sites can be harmful for water resources. They are therefore regulated by the following laws:

- Federal Toxic Substances Control Act-governs the manufacturing, disposing, importing, distribution, use, and processing of all toxic chemicals, with "toxic chemicals" being defined as those chemicals that present unreasonable risk of injury to public health or the environment. For more information, see http://edis.ifas.ufl.edu/fe591.

- Federal Resource Conservation and Recovery Act-manages hazardous wastes (i.e., wastes that are potentially harmful to human health or the environment) as well as non-hazardous solid wastes. For more information, see relevant documents listed below:

- Resource Conservation and Recovery Act-http://edis. ifas.ufl.edu/fe583

- Solid Waste Management-http://edis.ifas.ufl.edu/fe611

- Hazardous Waste Management-http://edis.ifas.ufl. edu/fe612

- Federal Comprehensive Environmental Response, Compensation, and Liability Act-includes provisions for investigation and cleanup of sites contaminated by hazardous substances (commonly referred to as brownfields) (see http://edis.ifas.ufl.edu/fe584).

- Federal Emergency Planning and Community Right-toKnow Act (EPCRA) —establishes requirements for federal, state, and local governments; Native American tribes; and chemical facilities regarding emergency planning for releases/spills of toxic chemicals, hazardous chemicals, or extremely hazardous substances, and community right-to-know reporting on toxic chemicals, hazardous chemicals, and extremely hazardous substances (see http://edis.ifas.ufl.edu/fe586).
Water resources may also be affected by various chemicals used in agriculture, and hence the following laws can apply to water resource protection:

- Federal Insecticide, Fungicide, and Rodenticide Actregulates all phases of pesticide sale, use, handling, and disposal (see http://edis.ifas.ufl.edu/fe588).

- Florida Pesticide Law - regulates the distribution, sale, and use of pesticides in Florida to protect people and the environment from the adverse effects of pesticides. To the extent that regulations under the FPL do not violate federal pesticide law (FIFRA and FQPA), the state pesticide regulations can be more restrictive than the federal ones (see http://edis.ifas.ufl.edu/fe590).

- Federal Food Quality Protection Act (FQPA)_protects the public from the health risks presented with exposure to excessive pesticide residues in/on foods and in the everyday surroundings, such as in the home and at work (see http://edis.ifas.ufl.edu/fe589).

- Florida Right-to-Farm Act-restricts nuisance lawsuits against farmers by providing that farm operations that have been in operation for one year or more since their established dates and that were not nuisances when they were established will not constitute a public or private nuisance if the farm operations conform to generally accepted agricultural and management practices. For more information on the Florida Right-to-Farm Act and to learn more about private lawsuits, see http://edis.ifas. ufl.edu/fe599.

\section{List of Government Agencies Involved in Water Resource Management}

In addition to FDEP and Florida's five WMDs that play a major role in water resource management, a few other agencies are responsible for protecting water resources. These are:

\section{- Florida Department of Agriculture and Consumer} Services (FDACS) - among other functions, conserves and protects the state's agricultural and natural resources by promoting environmentally safe agricultural practices. Within FDACS is the Office of Agriculture Water Policy, which works with farmers and businesses to develop and implement best management practices (BMPs) to protect and improve water quality. While agencies offer various definitions of BMPs, in general they are management and cultural practices that allow farmers to get the most beneficial use out of their land while preserving regional 
water resources. In addition, FDACS administers a pesticide review and registration program to assure that pesticides labeled for use in Florida have been tested under Florida's conditions and will not pose an unreasonable threat to water quality. For more information on FDACS, see the relevant chapter of this handbook at http://edis.ifas.ufl.edu/fe596.

- Florida Fish and Wildlife Conservation Commission (FFWCC) - the agency is responsible for the management, protection, and conservation of wild animal life, fresh water aquatic life, and marine life. For more information on FFWCC, see the relevant chapter of this handbook at http://edis.ifas.ufl.edu/fe595.

- Florida Department of Health (FDOH)-the agency is responsible for implementing procedures to promote and protect public health and safety. Farmers must contact FDOH when they are involved in activities that might pollute public drinking supplies. FDOH conducts investigations on wells or specific areas when they are potentially at risk due to a chemical release and provides an alternate drinking source when the water exceeds the maximum contaminant level. For more information on FDOH, see the relevant chapter of this handbook at http://edis.ifas.ufl.edu/fe597.

\section{Conclusions}

This document provides a short overview of the history of Florida's water quality and quantity laws. Other chapters in will go into further depth on current regulations and laws affecting water.

More information is available from excellent websites maintained by the resource and environmental management agencies in Florida, including:

- South Florida Water Management District, West Palm Beach, http://www.sfwmd.gov

- Southwest Florida Water Management District, Brooksville, http://www.swfwmd.state.fl.us

- Saint Johns River Water Management District, Palatka, https://www.sjrwmd.com

- Suwannee River Water Management District, Live Oak, http://www.srwmd.state.fl.us

- Northwest Florida Water Management District, Havana, http://www.nwfwmd.state.fl.us

- Florida Department of Environmental Protection, Tallahassee, http://www.dep.state.fl.us
- Florida Department of Agriculture and Consumer Services, Tallahassee, http://www.freshfromflorida. com/\#Water

Each of these agencies maintains service centers at locations remote from the main office locations listed above.

\section{References}

Lamm, A., and Pei-wen Huang. 2016. "Water Quality Assurance Act - What is it and how can we talk about it?" Water Policy. http://www.piecenter.com/pep/wp-content/ uploads/PEP_WQAA_Final.pdf

Ausness, R.C. 1987. Influence of the model water code on water resources management policy in Florida. Journal of Land Use and Environmental Law 3(1): 1-32. http://ufdc. ufl.edu/WL00001941/00001

CERP. 2013. Comprehensive Everglades Restoration Plan (CERP) Website. http://www.evergladesplan.org/

FDACS. 2013. Fresh from Florida. Florida Department of Agriculture and Consumer Services, Tallahassee, FL. http:// www.freshfromflorida.com/

FDEP. 2013a. Florida Water Program Website. Florida Department of Environmental Protection, Tallahassee, FL. http://www.dep.state.fl.us/water/

FDEP. 2013b. What Is the Environmental Resource Permit (ERP) Program? http://www.dep.state.fl.us/water/wetlands/ $\operatorname{erp} /$

FDEP. 2013c. TMDL Website. Florida Department of Environmental Protection, Tallahassee, FL. http://www.dep. state.fl.us/water/tmdl/

Florida Statutes. 2013. Florida Water Resources Act of 1972. Chapter 373, Florida Statutes, Tallahassee, FL. http://www. dep.state.fl.us/water/stormwater/npdes/docs/ch373.pdf

Florida's Water Management Districts Permitting Portal. 2013. http://flwaterpermits.com/

Maloney, F.E. 1957. Florida’s new water resources law. University of Florida Law Review 10(2): 119-153. 